\title{
Iberian Odonata distribution: data of the BOS Arthropod Collection (University of Oviedo, Spain)
}

\author{
Antonio Torralba-Burrial', Francisco J. Ocharan ${ }^{2}$ \\ I Universidad de Oviedo, Cluster de Energía, Medioambiente y Cambio Climático, Plaza de Riego 4, 33071, \\ Oviedo, Spain 2 Universidad de Oviedo, Biologia Organismos y Sistemas, 33071, Oviedo, Spain \\ Corresponding author: Antonio Torralba-Burrial (antoniotb@hotmail.com)
}

Academic editor: V. Chavan | Received 9 April 2013 | Accepted 29 May 2013 | Published 3 June 2013

Citation: Torralba-Burrial A, Ocharan FJ (2013) Iberian Odonata distribution: data of the BOS Arthropod Collection (University of Oviedo, Spain). ZooKeys 306: 37-58. doi: 10.3897/zookeys.306.5289 Resource ID: GBIF key: http:// gbrds.gbif.org/browse/agent?uuid=7e31baf8-f762-11e1-a439-00145eb45e9a

Resource citation: Torralba-Burrial A, Ocharan FJ (2013 -). BOS Arthropod Collection Dataset: Iberian Odonata distribution. 16604 data records. Contributed by Torralba-Burrial A, Ocharan FJ, Outomuro D, Ocharan R, Salona MI, Benitez-Donoso A, Martinez JA, Martinez SR, and Brotons-Padilla M. Online at http://www.gbif.es:8080/ipt/ archive.do? $\mathrm{r}=$ Bos-Odo and http://www.unioviedo.es/BOS/Zoologia/artropodos/odonata, version 1.0 (last updated on 2013-04-08), GBIF key: http://gbrds.gbif.org/browse/agent?uuid=7e31baf8-f762-11e1-a439-00145eb45e9a. Data Paper ID: doi: $10.3897 /$ zookeys.306.5289

\begin{abstract}
Odonata are represented from the Iberian Peninsula by 79 species. However, there exists a significant gap in accessible knowledge about these species, especially regarding their distribution. This data paper describes the specimen-based Odonata data of the Arthropod Collection of the Department of Biología de Organismos y Sistemas (BOS), University of Oviedo, Spain. The specimens were mainly collected from the Iberian Peninsula (98.63\% of the data records), especially the northern region. The earliest specimen deposited in the collection dates back to 1950, while the 1980's and 2000's are the best-represented time periods. Between 1950 and 2009, 16,604 Odonata specimens were deposited and are documented in the dataset. Approximately $20 \%$ of the specimens belong to the families Coenagrionidae and Calopterygidae. Specimens include the holotype and paratypes of the Iberian subspecies Calopteryx haemorrhoidalis asturica Ocharan, 1983 and Sympetrum vulgatum ibericum Ocharan, 1985. The complete dataset is also provided in Darwin Core Archive format.
\end{abstract}

\section{Keywords}

Odonata, Arthropoda, Iberian Peninsula, Entomological collections, Biodiversity collections, Distribution, datasets, Spain

Copyright A. Torralba-Burrial, F.J. Ocharan. This is an open access article distributed under the terms of the Creative Commons Attribution License 3.0 (CC-BY), which permits unrestricted use, distribution, and reproduction in any medium, provided the original author and source are credited. 


\section{General description}

Purpose: The purpose of this dataset is to make data associated with Odonata specimens deposited in the BOS Arthropod Collection (subcollection of Odonata: BOS-Odo) of the University of Oviedo, Spain. Iberian Odonata (and available data sets) and dragonfly data records are scanty when compared with the distribution data records from other European countries (e.g. Belgium, France, Germany, United Kingdom). Prior to publishing of this dataset, only 2700 data records associated with Iberian Odonata are accessible through GBIF data portal [accessed 2013/04/04], where as nearly 12000 data records from Iberian region for the period 1784-2009 can be tagged or extracted from various publications (includes authors unpublished data), some of which cite the specimens deposited in BOS Arthropod Collection (few listed in reference section). As depicted in Figure 1, other European data sets on dragonfly exceed by far the Iberian available records. For instance, British Odonata database comprises 500,000 records (Parr 2010), Dutch database more than 307,000 (Termaat et al. 2010), North Rhine-Westphalia 150,000 (Conce et

\section{Odonata records in some European datasets}

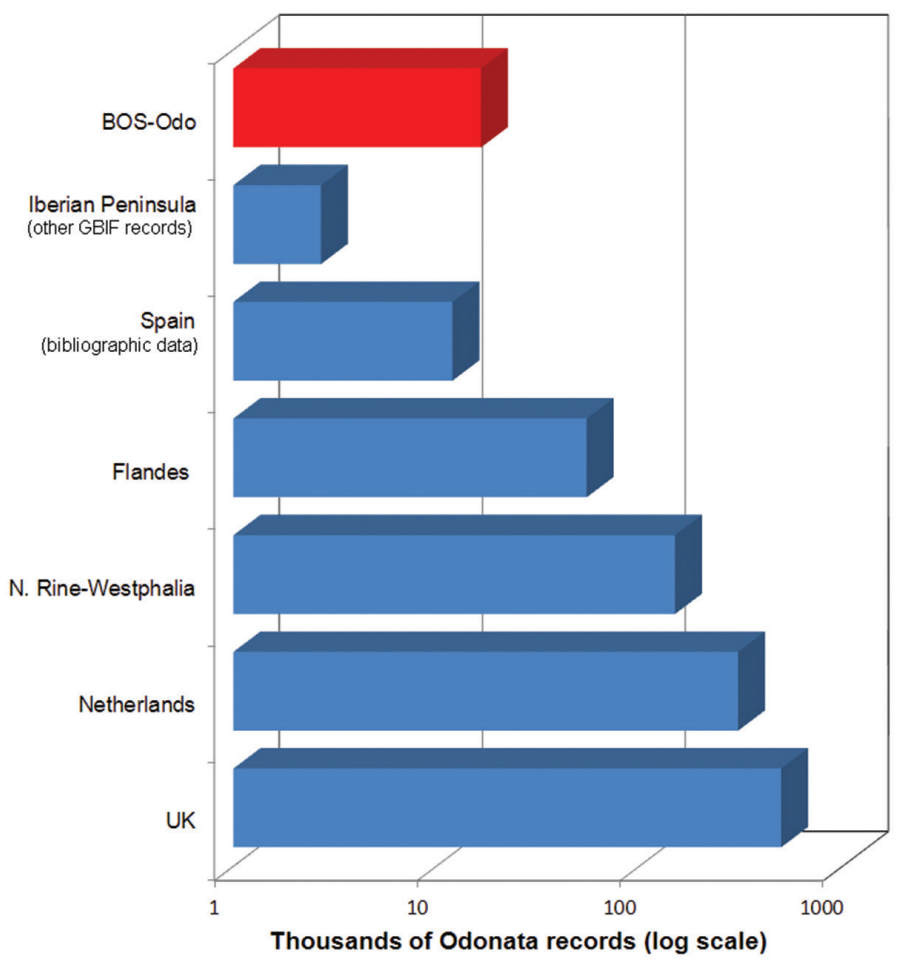

Figure I. Odonata data records in major European data sets. Sources: BOS-Odo (this dataset); Flandes (De Knijf and Anselin 2010); Iberian Peninsula other GBIF data (GBIF dataportal http://data.gbif.org); Netherlands (Termaat et al. 2010); North Rhine-Westphalia (Conce et al. 2010); United Kingdom (Parr 2010). 
al. 2010) or Flandes 55,000 (De Knijf and Anselin 2010). On this backdrop, the BOS-Odo dataset makes significant contribution of primary data about Iberian odonates for ecological, faunistic and conservation studies. Therefore main objective of this data set development were three fold; (1) provide a large dataset with primary distribution data of Iberian Odonata, (2) describe the Odonata subcollection of the BOS Arthopod Collection, (3) promote increasing inhouse and external use of the Collection and the biodiversity data associated.

Additional information: A list of publications citing Iberian odonate data contained in this dataset is provided in point 2 of reference section.

\section{Project details}

Project title: Informatización de la Colección de Artrópodos BOS de la Universidad de Oviedo / Digitisation of the BOS Arthropod Collection of University of Oviedo.

Project personnel: Antonio Torralba-Burrial

Former curator and promoter: Francisco J. Ocharan

Another administrative contact: Araceli Anadón.

BOS-Odo collectors: Collectors who have deposited more than 50 specimens include Antonio Torralba-Burrial, Francisco .J. Ocharan, David Outomuro, Rocío Ocharan, Marta I. Saloña, Antonio Benítez-Donoso, José Alberto Martínez, Saúl Rodríguez-Martínez, Matías Brotons-Padilla.

Funding: Digitisation of this biological collection is supported by Spanish National R+D+i Plan (MICINN, Spanish Government, grant ref. PTA2010-4108-I) and PCTI Asturias (Asturias Regional Government, ref. COF11-38) through a contract for ATB.

Study area descriptions/descriptor: Majority of the Odonata specimens deposited in BOS Arthropod Collection are from Iberian Peninsula, which has a geographic extent of $581,300 \mathrm{~km}^{2}$, located between latitude $36^{\circ}$ and $43^{\circ} 47^{\prime} \mathrm{N}$, and between longitude $3^{\circ} 29^{\prime} \mathrm{E}$ and $9^{\circ} 29^{\prime} \mathrm{W}$, placed at southwest end of Europe. The geographic location and relief distribution of the Iberian Peninsula was responsible for it being glacial refuge (and speciation centre) for many groups of organisms during quaternary period, with limited contact with the rest of the continent. Later on se-veral faunal species belonging to other regions colonised the Iberian Peninsula, which makes it an interesting place for biogeographic or distribution range variations linked to climate change studies. Climatic variation in the Iberian Peninsula is diverse, with annual average air temperature ranges between $2.5^{\circ} \mathrm{C}$ in high mountains in the north (Pyrenees) and $17^{\circ} \mathrm{C}$ in thermo-Mediterranean zones in the south. Annual average rainfall varies between less than $200 \mathrm{~mm}$ in south east (e.g. some zones in Almeria province) and about $2200 \mathrm{~mm}$ in the north-west (north Portugal and south Galicia) (AEMET and IM 2011). This climate variation can be analysed in a bioclimatic belts scheme (Rivas-Martínez 1987) or a Köppen-Geiger climate classification system (AEMET and IM 2011). Both systems shown a more humid zone in the north and more dry 


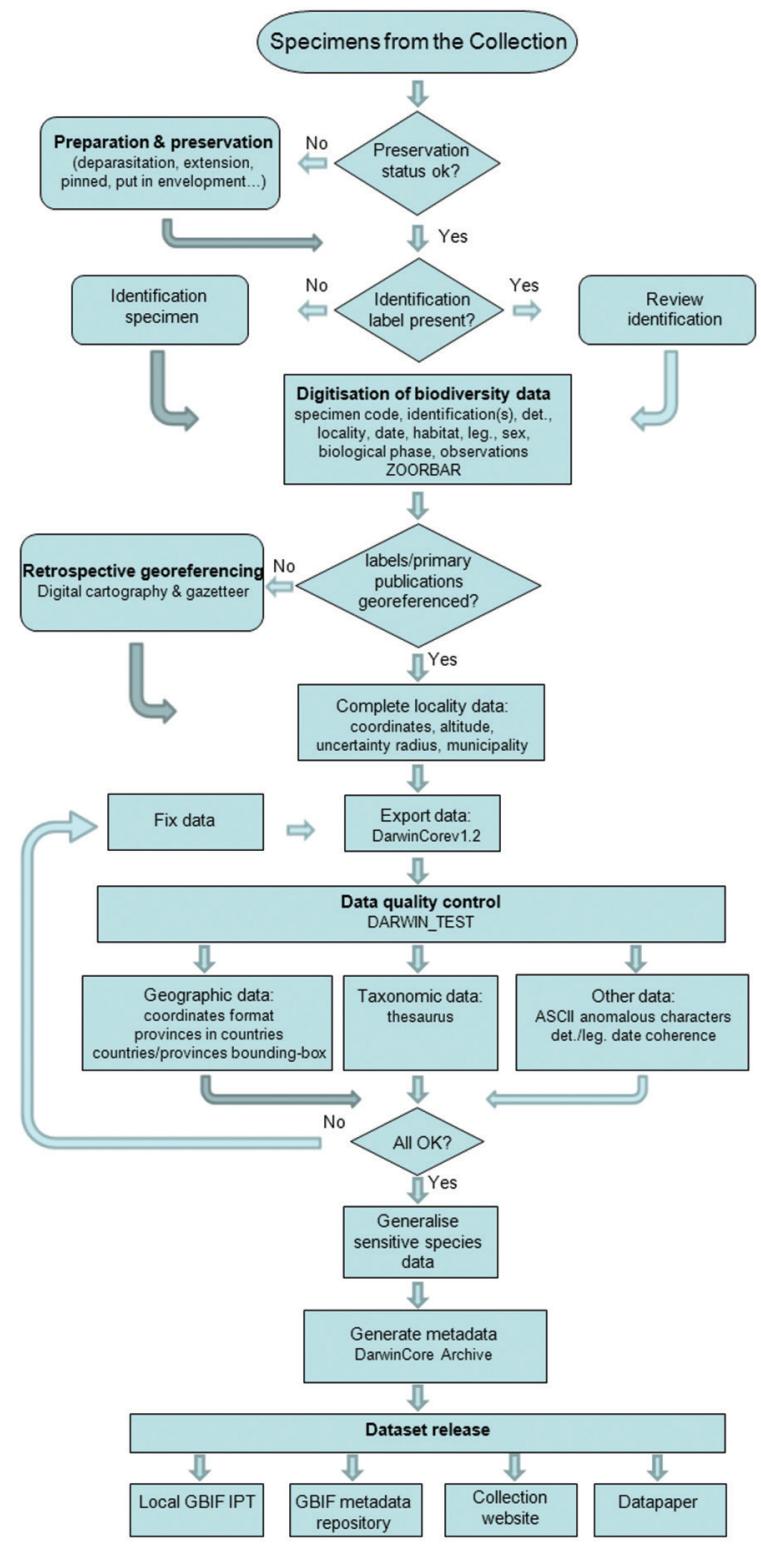

Figure 2. BOS Arthropod Collection digitisation and data publishing workflow.

in the rest of the Iberian Peninsula, although mountain ranges in this zone have their peculiar less dry/less thermic climates.

According to the European Union Habitats Directive (Directive 92/43/CEE), most of the Iberian Peninsula is included in the Mediterranean region, with a narrow band in the north belonging to the Atlantic region and a bit of the Alpine region in the 
Pyrenees Mountains (biogeographic regions based on vegetation types are the same: Rivas-Martínez et al. 2004). Geographic limits between Mediterranean region and the other are along the southern slopes of the Cantabrian and Pyrenean ranges and in Galicia/northwest of Portugal. Although classification of limnological regions shows the first two bioregions joined in the Iberic-Macaronesian region and the Pyrenees retain as a separate region (Illies, 1978, adopted in the Water Framework European Directive, Directive 2000/60/CE) and odonates are aquatic organism, their Iberian distribution seems better explained in the bioclimatic belts scheme (e.g., Brotons et al. 2009, Outomuro et al. 2010).

Design description: Figure 2, depicts the digitisation workflow. Prior to digitisation, specimen is carefully examined for its preservation status and if necessary, curative treatment is provided. Subsequent to this taxonomic identification status is examined. In case of non-identified specimens, taxonomic identification is carried out involving experts. Thereafter, data associated with specimens is digitised using ZOORBAR software. In case of absence of precise geo-coordinates, retrospective georeferencing is carried out. If the geo-coordinates are present, they are verified using digital cartography. Best practices as suggested by Chapman 2005a, Chapman and Wieczorek 2006 are followed for the geo-referencing processes. Current accurate spelling of scientific names (Askew 2004, Dijkstra and Lewington 2006) and identification of specimens were reviewed in laboratory with suitable literature (Heidemann and Seidenbusch 2002, Askew 2004, Dijkstra and Lewington 2006, Doucet 2010) as there are explained at quality controls section.

\section{Taxonomic coverage}

General taxonomic coverage description: All specimens were identified to species or subspecies level with the help of authoritative literature (Heidemann and Seidenbusch 2002, Askew 2004, Dijkstra and Lewington 2006, Doucet 2010) and expert input. All nine dragonfly families recorded from the Iberian Peninsula are present in the collection and dataset. As shown in Figure 3, Coenagrionidae and Calopterygidae are the most abundant families in the BOS Arthropod Collection: each represents approximately $21 \%$ of the total specimens deposited. The next most abundant families are the Libellulidae and Gomphidae, each representing approximately $16 \%$ of the total specimens deposited. Of the 79 species of known Odonata from the Iberian Peninsula (Torralba Burrial 2009, Mezquita Aranburu et al. 2011), 71 have specimens deposited in the BOS Arthropod Collection. Table 1 provides an account of the number of specimens of key taxa. The BOS Arthropod Collection also includes the holotype and paratypes of the Iberian subspecies Calopteryx haemorrhoidalis asturica Ocharan, 1983 and Sympetrum vulgatum ibericum Ocharan, 1985 (Table 2). Records of four protected species and nine threatened species (sensu the last update of the Spanish Invertebrate Red List: Verdú et al. 2011) are also included in the dataset. Details about the type specimens and those of threatened and protected species housed in the BOS Arthropod Collection are provided in Table 2. 


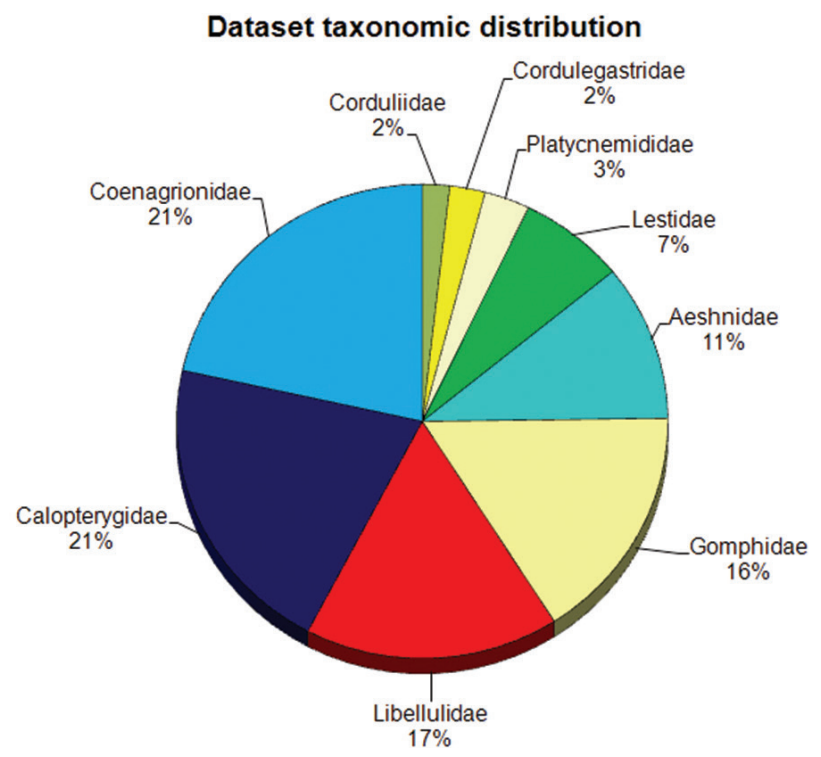

Figure 3. Taxonomic distribution of the Iberian Odonata BOS-Odo dataset.

Table I. Taxonomic spread of specimens housed in BOS Arthropod collection.

\begin{tabular}{c|c|c|c}
\hline Taxa & Nos. of genera & Nos. of species & Nos. of specimens in the collection \\
\hline Family Calopterygidae & 1 & 4 & 3114 \\
\hline Genus Calopteryx & & 4 & 3114 \\
\hline Family Coenagrionidae & 6 & 14 & 3578 \\
\hline Genus Ceriagrion & & 1 & 203 \\
\hline Genus Coenagrion & & 5 & 872 \\
\hline Genus Enallagma & & 1 & 434 \\
\hline Genus Erythromma & & 2 & 267 \\
\hline Genus Ischnura & & 4 & 1453 \\
\hline Genus Pyrrhosoma & & 1 & 349 \\
\hline Family Lestidae & 3 & 6 & 1160 \\
\hline Genus Chalcolestes & & 1 & 403 \\
\hline Genus Lestes & & 4 & 644 \\
\hline Genus Sympecma & & 1 & 113 \\
\hline Family Platycnemididae & 1 & 3 & 499 \\
\hline Genus Platycnemis & & 3 & 499 \\
\hline Family Aeshnidae & & 13 & 4774 \\
\hline Genus Aeshna & & 7 & 6 \\
\hline Genus Anaciaeschna & & 1 & 240 \\
\hline Genus Anax & & 3 & 5842 \\
\hline Genus Boyeria & & 1 & 387 \\
\hline Genus Brachytron & & 1 & \\
\hline Family Cordulegastridae & 1 & 2 & 5 \\
\hline Genus Cordulegaster & 1 & 2 & \\
\hline
\end{tabular}




\begin{tabular}{c|c|c|c}
\hline Taxa & Nos. of genera & Nos. of species & Nos. of specimens in the collection \\
\hline Family Corduliidae & 4 & 5 & 297 \\
\hline Genus Cordulia & & 1 & 2 \\
\hline Genus Macromia & & 1 & 2 \\
\hline Genus Oxygastra & & 1 & 290 \\
\hline Genus Somatochlora & & 2 & 2687 \\
\hline Family Gomphidae & 2 & 7 & 97 \\
\hline Genus Gomphus & & 4 & 2590 \\
\hline Genus Onychogomphus & & 3 & 2778 \\
\hline Family Libellulidae & 8 & 24 & 13 \\
\hline Genus Brachythemis & & 1 & 321 \\
\hline Genus Crocothemis & & 1 & 2 \\
\hline Genus Leucorrhinia & & 1 & 179 \\
\hline Genus Libellula & & 3 & 565 \\
\hline Genus Orthetrum & & 7 & 1 \\
\hline Genus Selysiothemis & & 1 & 41 \\
\hline Genus Sympetrum & & 7 & 2 \\
\hline Genus Trithemis & & 2 & 16604 \\
\hline Genus Zygonyx & & 1 &
\end{tabular}

Table 2. Type specimens and specimens of threatened and protected species housed in BOS Arthropod collection.

\begin{tabular}{|c|c|c|c|}
\hline Scientific name & BOS-Odo ID & * & Reference \\
\hline Aeshna juncea (Linnaeus, 1758) & $\begin{array}{c}\text { 1201-1213, 4421, 4665-4668, 6736-6737, } \\
9499-9507,10000-10002,12120-12126 \\
13983-13985,16235-16237\end{array}$ & $\mathrm{~T}$ & Verdú et al. 2011 \\
\hline Brachytron pratense (Müller, 1764) & $1268-1271,5668$ & $\mathrm{~T}$ & $\begin{array}{c}\text { Verdú and } \\
\text { Galante } 2009\end{array}$ \\
\hline \multirow[b]{2}{*}{$\begin{array}{c}\text { Calopteryx haemorrhoidalis asturica } \\
\text { Ocharan, } 1983\end{array}$} & 3715 & $\mathrm{H}$ & Ocharan1983 \\
\hline & $\begin{array}{c}3705-3714,3716-3756,3775-3804,7381- \\
7385,7393\end{array}$ & $\mathrm{P}$ & Ocharan1983 \\
\hline $\begin{array}{l}\text { Coenagrion caerulescens } \\
\text { (Fonsbolombe, 1838) }\end{array}$ & $\begin{array}{c}1944-1972,4096-4100,4972-4980,5077- \\
\text { 5079, 5777-5079, 5787-5788, 6123-6158, } \\
6560-6561,7115-7140,11608,11830- \\
11831,14367-14375\end{array}$ & $\mathrm{~T}$ & Verdú et al. 2011 \\
\hline $\begin{array}{l}\text { Coenagrion mercuriale } \\
\text { (Charpentier, 1840) }\end{array}$ & $\begin{array}{c}1877-1943,3894-4005,4101-4124,5109- \\
5125,5475-5476,5738-5739,5759,6054- \\
6086,7141-7156,8102-8106,8374-8380, \\
11609-11620,14354-14362\end{array}$ & $\mathrm{~L}$ & Verdú et al. 2011 \\
\hline Coenagrion scitulum (Rambur, 1842) & $\begin{array}{c}2012-2035,4158-4162,5068-5076,5766- \\
5770,8373,11595-11607,11810-11819 \\
14364-14366\end{array}$ & $\mathrm{~T}$ & Verdú et al. 2011 \\
\hline Cordulegaster bidentata Selys, 1843 & 2847 & $\mathrm{~T}$ & Verdú et al. 2011 \\
\hline Gomphus graslinii Rambur, 1842 & $\begin{array}{c}4655-4656,7258-7259,13867-13868 \\
13883,13931,14205-14215,16072-16074\end{array}$ & $\mathrm{~L}$ & $\begin{array}{c}\text { Verdú and } \\
\text { Galante } 2009\end{array}$ \\
\hline Gomphus simillimus Selys, 1840 & $\begin{array}{c}798,4561,5962,6993,8048-804,13869- \\
13882,13972,14203-14204,14401-14402 \\
15924-15929,16075-16077,16128\end{array}$ & $\mathrm{~T}$ & Verdú et al. 2011 \\
\hline
\end{tabular}




\begin{tabular}{c|c|c|c}
\hline Scientific name & BOS-Odo ID & $*$ & Reference \\
\hline $\begin{array}{c}\text { Gomphus vulgatissimus } \\
\text { (Linnaeus, 1758) }\end{array}$ & $797,5327-5328,8051-8052,16241$ & T & Verdú et al. 2011 \\
\hline Macromia splendens (Pictet, 1843) & $14197-14198$ & L & $\begin{array}{c}\text { Verdú and } \\
\text { Galante 2009 }\end{array}$ \\
\hline Onychogomphus costae Selys, 1885 & $5963,6779-6780,11788$ & T & Verdú et al. 2011 \\
\hline Orthetrum nitidinerve (Selys, 1841) & $592-593,3064$ & T & Verdú et al. 2011 \\
\hline Oxygastra curtisii (Dale, 1834) & $\begin{array}{c}789-792,4333-4335,8041,14186-14196, \\
14269-14275,14612-14689,14923-15019, \\
15543-15596,16026-16059\end{array}$ & L & $\begin{array}{c}\text { Verdú and } \\
\text { Galante 2009 }\end{array}$ \\
\hline Sympetrum flaveolum (Linnaeus, 1758) & $\begin{array}{c}187-193,2871-2873,2901,4633-4634, \\
4645,16133-16135,16209-16233\end{array}$ & T & Verdú et al. 2011 \\
\hline $\begin{array}{c}\text { Sympetrum striolatum } \\
\text { (Charpentier, 1840) }\end{array}$ & 16245,16247 & G & $\begin{array}{c}\text { Torralba- } \\
\text { Burrial and } \\
\text { Ocharan 2009 }\end{array}$ \\
\hline $\begin{array}{c}\text { Sympetrum vulgatum ibericum } \\
\text { Ocharan, 1985 }\end{array}$ & $194-206,5640$ & P & \begin{tabular}{l} 
Ocharan 1985 \\
\hline
\end{tabular}
\end{tabular}

*: $\mathrm{G}=$ gynandromorph, $\mathrm{H}=$ holotypus; $\mathrm{L}=$ legally protected species; $\mathrm{P}=$ paratypus; $\mathrm{T}=$ threatened sp. in Spain.

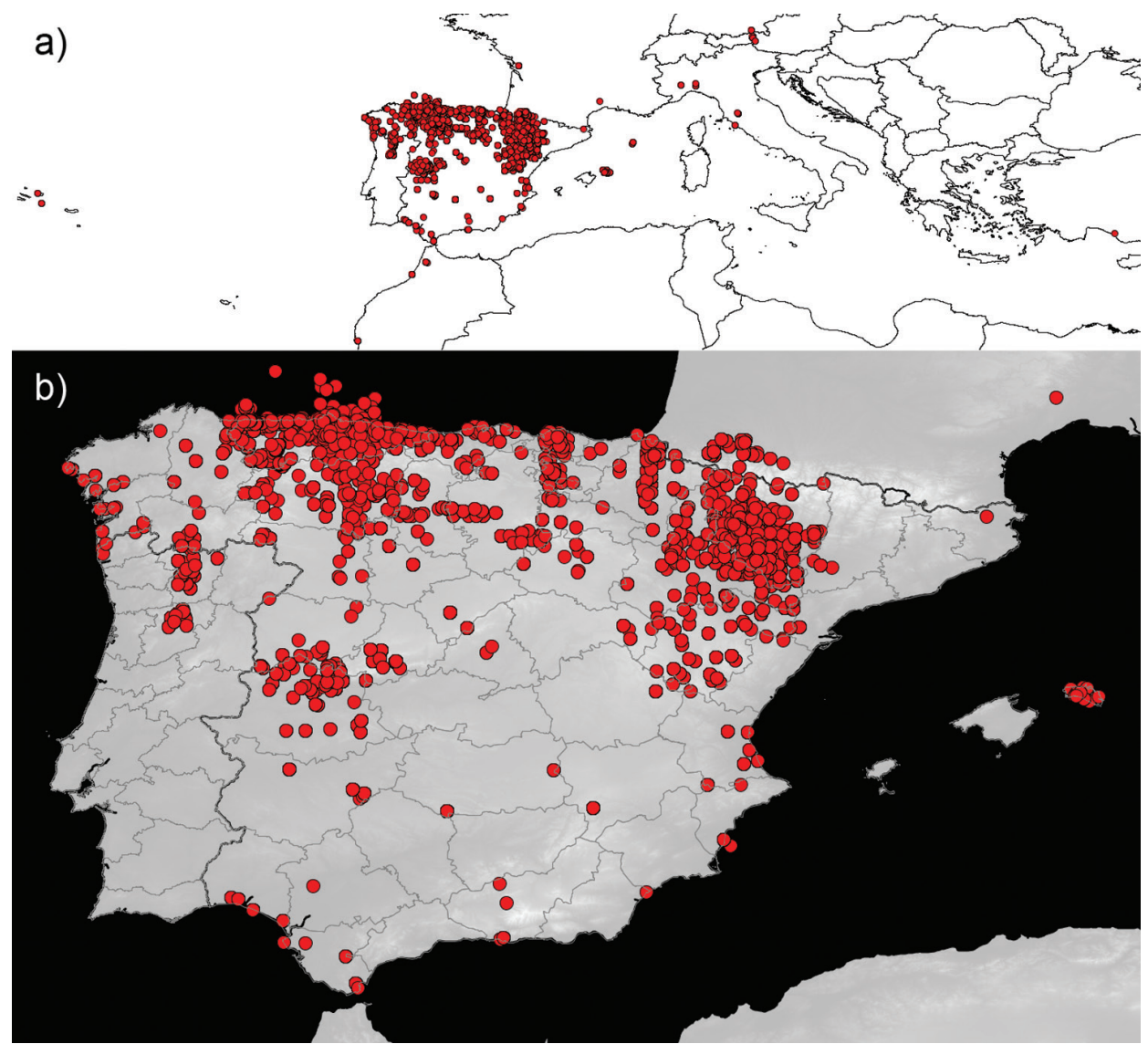

Figure 4. Geographic distribution of specimens in the BOS-Odo dataset: a global distribution $\mathbf{b}$ Iberian distribution. 


\section{Taxonomic ranks}

Kingdom: Animalia

Phylum: Arthropoda

Class: Insecta

Order: Odonata

Family: Calopterygidae, Coenagrionidae, Lestidae, Platycnemididae, Aeshnidae, Cordulegastridae, Corduliidae, Gomphidae, Libellulidae.

Common names: Dragonflies, Insects, Arthropods.

\section{Spatial coverage}

General spatial coverage: As evident from Figure 4, majority of the specimens (98.63\% of total data) are from the Iberian Peninsula (mainly Spain, but also records of Portugal). The Northern part of the Peninsula is better covered: Asturias ( -4100 specimens) and Huesca $(-3400)$ are the provinces with more exemplars, followed by Navarra, Teruel, Zaragoza, León, Álava and Vizcaya (between 1700-500 records). Data of other 32 Spanish provinces and 2 old Portuguese continental provinces (3 districts) are available in the database (Fig. 5). Other countries appear in the collection with few specimens: Morocco and Austria, the following countries by specimens, have 40 registers each one.

Coordinates: $30^{\circ} 0^{\prime} 0^{\prime \prime} \mathrm{N}$ and $47^{\circ} 0^{\prime} 0^{\prime \prime} \mathrm{N}$ Latitude; $27^{\circ} 0^{\prime} 0^{\prime \prime} \mathrm{W}$ and $32^{\circ} 0^{\prime} 0^{\prime \prime} \mathrm{E}$ Longitude.

\section{Temporal coverage}

$1950-2012$.

\section{Natural collections description}

Parent collection identifier: Colección de Artrópodos BOS

Collection name: Colección de Artrópodos BOS de la Universidad de Oviedo: Odonata (BOS-Odo)

Collection identifier: http://data.gbif.org/datasets/resource/12776/

Specimen preservation method: Specimens are preserved as dry specimens (pinned or in transparent envelopes or in tubes) or in $70^{\circ}$ ethanol, sorted alphabetically by family/genus/species and numerically by specimen code in drawers of metallic mobile cabinets in a cold chamber at $6{ }^{\circ} \mathrm{C}$. In drawers with dry specimens paradichlorobenzene is used as insecticide, an additional protection for when the drawers are taken to the lab for study (see Barrientos 2004).

Curatorial unit: 16604 with an uncertainty of 0 (Specimens) 


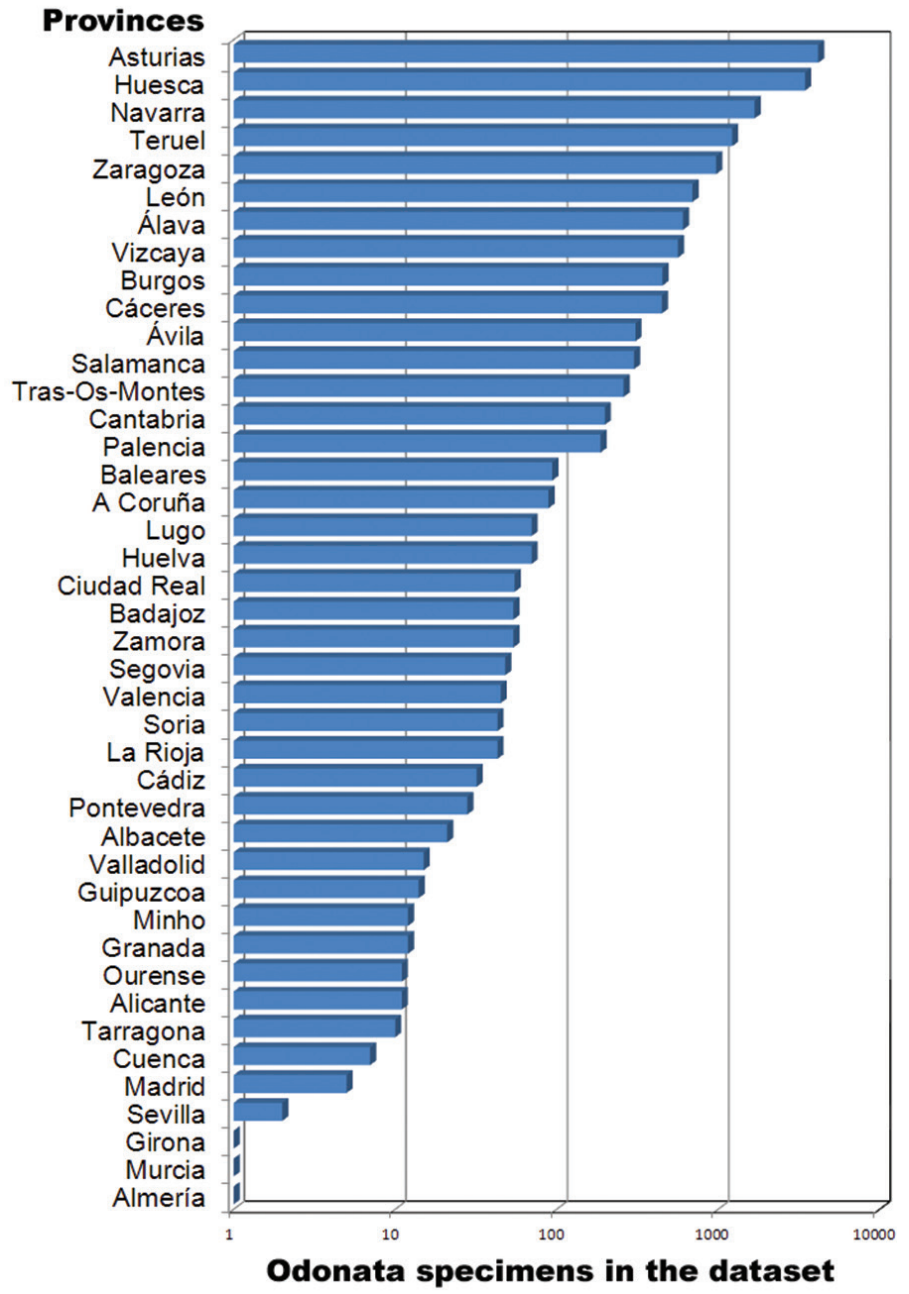

Figure 5. Specimens in each Spanish/Portuguese provinces in the BOS-Odo dataset.

\section{Methods}

Method step description: The processing workflow is shown in Figure 2. Prior to digitisation, odonate specimens in the BOS Arthropod Collection were examined and their preservation status revised: specimens were pinned, labelled and frozen to deparasitize when necessary. The status of the prepared specimens is now as follows: half (48\%) of the specimens hosted in the collection are pinned adults, 22\% are preserved in $70 \%$ ethanol, $18 \%$ are dried exuviae and $11 \%$ are dry specimens in transparent envelopes. All specimens are stored in metal cabinets in a cold chamber $\left(6^{\circ} \mathrm{C}\right)$. More information about these preparation and preservation methods can be found in Entomology handbooks (e.g., Barrientos 2004). Dry specimens pinned before the year 2000 were in entomological boxes with naphthalene as an insecticide; this product was later replaced 
by paradichlorobenzene. Use of these insecticides does not seem to impede the extraction and amplification of DNA from specimens (Espeland et al. 2010), but it can affect specimens' colours (Dawson 1988) and researchers' health (see Guerrero and Corsi 2012 for a recent review of these insecticide effects). The amount of insecticides used in the BOS Arthropod Collection has been reduced in recent years for these reasons.

If a dragonfly specimen had been identified before the digitisation process, then its identification was revised. When the identification label was lacking or incomplete, specimens were identified with suitable literature (see section on quality control). All biodiversity data available on the specimens' labels (i.e., specimen code, species identification and name of determiner, sex, biological phase, locality, date, habitat, collector and observations) were included in a database using ZOORBAR software (http:// www.gbif.es/zoorbar/zoorbar.php), which exports data in Darwin Core (v1.2) format.

A taxonomic thesaurus was developed that includes all synonyms used in Iberian Odonata publications and spelling variants of scientific names. The thesaurus was used to convert the species identifications archived in the offline database (i.e., the species names appearing on the original specimen labels) to the correct/verified scientific name prior to being exported to the online ZOORBAR database.

Other geographic data (municipality, GPS coordinates, altitude, etc.) from specimen labels or associated publications were added to the database when available. GPS coordinates (in UTM/MGRS format) were included without resolution changes (grids of $10 \times 10 \mathrm{~km}$ or $1 \times 1 \mathrm{~km}$ are common in entomological studies); ZOORBAR converts the coordinates to decimal degrees and fills out the uncertainty radius at the export data step. Retrospective georeferencing of specimens (see Chapman and Wieczorek 2006) was carried out using digital cartography tools (Google Earth and IBERPIX) if coordinates were not present on the specimen labels or in primary publications. Google Earth can be used to obtain locality coordinates and altitude; it also incorporates a measurement tool that can be used to calculate the uncertainty radius of the place georeferenced. IBERPIX (http://www2.ign.es/iberpix/visoriberpix/visorign. html) is a public gazetteer combining data, maps, satellite images and orthophotographs compiled by the Spanish National Geographic Institute, with a better searchable toponyms database. An accurate, effective, reliable and quick georeferencing process can be acheived by combining the information provided by both tools. Records were sorted geographically for batch retrospective georeferencing, starting with larger batches (Chapman and Wieczorek 2006).

Biodiversity data were exported to a dataset in Darwin Core (v1.2) format. DARWIN_TEST software was used to validate and clean the geographic, taxonomic and additional data associated with the specimens. Erroneous data were corrected and data cleaning was repeated to enhance the data quality (see details in the section on quality control).

Coordinates of threatened species protected by law (e.g., Macromia splendens, Oxygastra curtisii, Gomphus graslinii and Coenagrion mercuriale, included in the European Union Habitats Directive and in the Spanish Catalogue of Threatened Species) have been generalised to $0.01^{\circ}$ in the online database (see Chapman and Grafton 2008 for details on generalising sensitive data). 
The dataset was transformed to a Darwin Core Archive format with metadata and was uploaded to the Integrated Publishing Toolkit (IPT v2.0.4) of the Spanish node of the Global Biodiversity Information Facility (GBIF) (http://www.gbif.es:8080/ipt). On the BOS Arthropod Collection website (http://www.unioviedo.es/BOS/Zoologia/artropodos), links to data pertaining to the BOS odonate specimens included in the GBIF data portal were also provided. The offline version of the dataset includes the identification history of each specimen (17846 items), the habitats in which the specimens were collected, and notes on materials derived from specimens (e.g., microscopic preparations, morphometric data, publications, etc.). This information is available on request.

Study extent description: Specimens are mainly from the north half of the Iberian Peninsula, and were collected between 1973 and 2012 (though there are some outliers from other territories or time periods). Half of the Iberian odonate records in the dataset are from the 2000s and a quarter from the 1980s, which can facilitate comparisons over time to assess changes in distribution related to global change, climate change or specific alterations of ecosystems.

Sampling description: Material deposited in the Odonata subcollection of the BOS Arthropod Collection has been collected in three ways (Fig. 6):

1) Specimens from $\mathrm{PhD}$ dissertations carried out at the University of Oviedo (Ocharan Larrondo 1987, Torralba-Burrial 2008, Outomuro Priede 2011) (54.75\% of specimens).

2) Specimens collected during research projects, contracts, and development studies in the Department of Biology of Organisms and Systems of the University of Oviedo (32.15\%).

3) Specimens from other sources: collections from students in Biology and Forestry Engineering programs at the University of Oviedo, practical courses and other sources (13.1\%).

Odonates from source types 1 and 2 were collected using standardized sampling methods according to the requirements of each $\mathrm{PhD}$ thesis or project. Specimens from source type 3 are considered to be derived from opportunistic, unplanned and nonstandardized sampling. General sampling methods include the collection of adult dragonflies with an entomological net (75.76\% of records), exuviae picked directly from a substrate $(18.35 \%)$, and larvae collected with an entomological net or a Surber sampler (5.82\%) (see Barrientos 2004, Torralba-Burrial and Ocharan 2007b).

Specimens deposited by Ocharan (1987) were collected mainly in the provinces of Asturias (42.14\%), Guipúzcoa (12.95\%), Burgos and Cáceres (both - 8.8\%), León (6.57\%), Cantabria and Vizcaya (both 3.2\%). Sampling was carried out with the intent to capture all species present in each locality. Specimens collected by TorralbaBurrial (2008) are from Aragón, and include adults (184 localities; sampling was performed until all species seen in each locality each day were captured, with a minimum two sampling sessions), larvae (standardized Surber samples from 140 fluvial reaches: Torralba-Burrial and Ocharan 2007a) and exuviae (visual search of the river banks of 


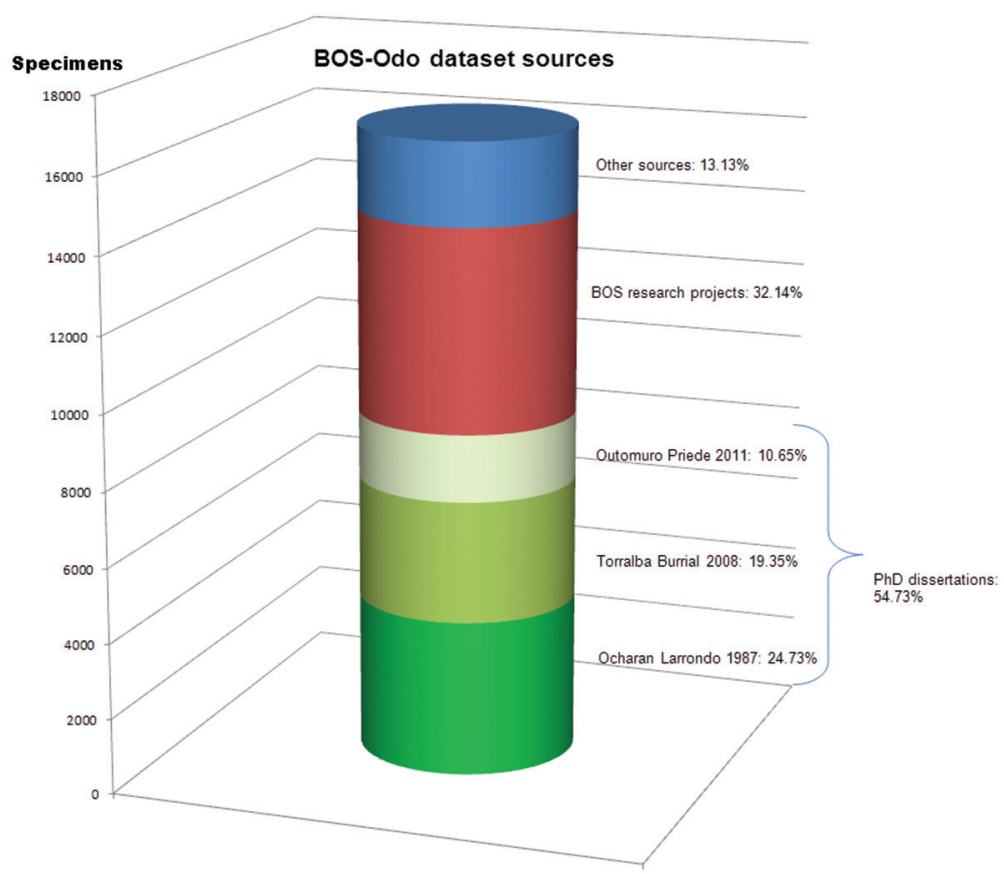

Figure 6. Sources of dragonfly specimens in this dataset.

the 140 reaches sampled, with at least two sampling sessions in each locality). Outomuro's (2011) specimens are almost all adults of Calopteryx spp.

It is not feasible to describe in detail the specific methodologies of each project or study of source 2), but all follow the general guidelines outlined above (examples of different methods in Martínez and Ocharan 2006, Torralba-Burrial and Ocharan $2007 b, 2008)$. In the last few years, conservation efforts have led to a reduction in the collection of adults and an increased use of photographic records (not included in the dataset) unless the sacrifice of specimens is deemed necessary.

Quality control description: Validation and cleaning of geographic, taxonomic and additional data associated with the dragonfly specimens was incorporated at several steps of the process (Fig. 2) as an essential component of the digitisation project (see Chapman 2005a,b).

The identifications of all specimens were revised (or performed for the first time when no determination label was available with the original material) by A. Torralba-Burrial between 2010-2012 using suitable literature (adults: Askew 2004, Dijkstra and Lewington 2006; larvae and exuviae: Heidemann and Seidenbusch 2002, Askew 2004, Doucet 2010).

Scientific names on labels were checked with a taxonomic thesaurus. This thesaurus was generated by the authors and includes all synonyms used in Iberian Odonata publications, as well as spelling variants of scientific names. Current European dragonfly taxonomy trends (Dijkstra and Lewington 2006, Dijkstra and Kalkman 2012) have been considered in the assignment of valid scientific names. Geographic data 
appearing on the original specimen labels were cross-checked with known published localities when available. Geographic/UTM/MGRS coordinates shown in published sources were assumed to be correct when no coordinates were included on the labels.

Unique collections' accession numbers were assigned to each specimen. Other validation procedures, including geographic coordinates format, coordinates within country/ provincial boundaries, congruence between collection and identification dates and absence of ASCII anomalous characters in the dataset were checked with DARWIN_TEST (v1.3) software (http://www.gbif.es/darwin_test/Darwin_test.php). Specimens with original MGRS coordinates in a $10 \times 10 \mathrm{~km}$ grid failed to meet the bounding-box validation in localities near coastlines and country or provincial boundaries, but these coordinates (converted to decimal degrees) were kept in the dataset with the estimated uncertainty radius.

\section{Datasets}

\section{Dataset description}

Object name: Darwin Core Archive Iberian Odonata distribution: data of the BOS Arthropod Collection of the University of Oviedo

Character encoding: UTF-8

Format name: Darwin Core Archive format

Format version: 1.0

Distribution: http://www.gbif.es:8080/ipt/archive.do?r=Bos-Odo

Publication date of data: 2013-04-08

Language: Spanish

Licenses of use: This dataset [Colección de Artrópodos BOS de la Universidad de Oviedo: Odonata (BOS-Odo)] is made available under the Open Data Commons Attribution License: http://www.opendatacommons.org/licenses/by/1.0/

\section{External datasets}

Dataset description

Object name: Colección de Artrópodos Biología de Organismos y Sistemas, Oviedo: odonatos

Character encoding: iso-8859-1

Format name: Darwin Core Archive

Format version: 1.0

Distribution: http://data.gbif.org/datasets/resource/12776

Metadata language: English

Date of metadata creation: 2013-03-20

Hierarchy level: Dataset 


\section{Acknowledgements}

Pablo Muñoz (Universidad Autónoma de Madrid) and Francisco Pando (Spanish GBIF node - CSIC) reviewed the manuscript and provided helpful comments. Vishwas Chavan and anonymous reviewers enhanced it with their suggestions. The Global Biodiversity Information Facility (GBIF) financed the publication of this data paper.

\section{References}

\section{1) References cited within the metadata}

AEMET IM (2011) Atlas climático ibérico / Iberian climate atlas. Agencia Estatal de Meteorología, Ministerio de Medio Ambiente y Rural y Marino, Madrid, Instituto de Meteorologia de Portugal, $80 \mathrm{pp}$.

Askew RR (2004) The dragonflies of Europe (revised edition). Harley Books, Colchester, 308 pp.

Barrientos JA (Ed) (2004) Curso práctico de Entomología. Asociación Española de Entomología, CIBIO Centro Iberoamericano de la Biodiversidad, Alicante, Universitat Autònoma de Barcelona, Bellaterra, $947 \mathrm{pp}$.

Boudot JP, Kalkman VJ, Azpilicueta Amorín M, Bogdanović T, Cordero Rivera A, Degabriele G, Domanget JL, Ferreira S, Garrigós B, Jović M, Kotarac M, Lopau W, Masrinov M, Mihoković N, Riservato E, Samraoui B, Schneider W (2009) Atlas of the Odonata of the Mediterranean and North Africa. Libellula Supplement 9: 1-256.

Brotóns Padilla M, Ocharan FJ, Outomuro D, Torralba-Burrial A (2009) Anaciaeschna isoceles (Müller, 1767) en el ámbito iberobalear (Odonata: Aeshnidae). Boletín de la Sociedad Entomológica Aragonesa 44: 365-374.

Chapman AD (2005a) Principles and Methods of Data Cleaning - Primary Species and SpeciesOccurrence Data, version 1.0. Global Biodiversity Information Facility, Copenhagen, 75 pp.

Chapman AD (2005b) Principles of Data Quality, version 1.0. Global Biodiversity Information Facility, Copenhagen, 61 pp.

Chapman AD, Grafton O (2008) Guide to Best Practices for Generalising Sensitive Species Occurence Data, version 1.0. Global Biodiversity Information Facility, Copenhagen, 27 pp.

Chapman AD, Wieczorek J (Eds) (2006) Guide to Best Practices for Georeferencing. Global Biodiversity Information Facility, Copenhagen, 90 pp.

Conze K-J, Grönhagen N, Lohr M, Menke N (2010) Trends in occurrence of thermophilous dragonfly species in North Rhine-Westphalia (NRW). BioRisk 5: 31-45. doi: 10.3897/ biorisk.5.841

Dawson J (1988) The effects on insecticides on museum artifacts and materials. In: Zycherman LA, Schrock JR (Eds) A guide to museum pest control. Foundation of the American Institute for Conservation of Historic and Artistic works and the Associations of Systematics Collections, Washington D.C., 135-150.

De Knijf G, Anselin A (2010) When south goes north: Mediterranean dragonflies (Odonata) conquer Flanders (North-Belgium). BioRisk 5: 141-153. doi: 10.3897/biorisk.5.855 
Dijkstra KDB, Kalkman VJ (2012) Phylogeny, classification and taxonomy of European dragonflies and damselflies (Odonata): a review. Organisms Diversity \& Evolution 12: 209-227. doi: 10.1007/s13127-012-0080-8

Dijkstra KDB, Lewington R (2006) Field guide to the Dragonflies of Britain and Europe. British Wildlife Publishing, Dorset, 320 pp.

Doucet G (2010) Clé de détermination des Exuvies des Odonates de France. Société française d'odonatologie, Bois-d'Arcy, 68 pp.

Espeland M, Irestedt M, Johanson KA, Åkerlund M, Bergh JE, Källersjö M (2010) Dichlorvos exposure impedes extraction and amplification of DNA from insects in museum collections. Frontiers in Zoology 7:2. doi: 10.1186/1742-9994-7-2

Guerrero PA, Corsi RL (2012) Emissions of p-dichlorobenzene and naphthalene from consumer products. Journal of the Air \& Waste Management Association 62: 1075-1084. doi: 10.1080/10962247.2012.694399

Heidemann H, Seidenbusch R (2002) Larves et exuvies des libellules de France et d'Allemagne (sauf de Corse). Société française d'odonatologie, Bois-d'Arcy, 416 pp.

Illies J (Ed) (1978) Limnofauna europaea. Gustav Fischer Verlag, Stuttgart, Swets \& Zeitlinger B. V. Amsterdam, 533 pp.

Martínez JA, Ocharan FJ (2006) Los odonatos de la cuenca alta del río Narcea (Asturias, norte de España). Boletín de la Sociedad Entomológica Aragonesa 38: 279-285.

Mezquita-Aranburu I, Ocharan FJ, Torralba-Burrial A (2011) Primera cita de Orthetrum albistylum (Sélys, 1848) (Odonata: Libellulidae) para la Península Ibérica. Boletín de la Asociación española de Entomología 35: 519-523.

Ocharan FJ (1983) Calopteryx haemorrhoidalis asturica, nueva subespecie de caballito del diablo del Norte de España (Odonata; Zygoptera). Boletín de Ciencias Naturales del Instituto de Estudios Asturianos 31: 3-10.

Ocharan FJ (1985) Sympetrum vulgatum ibericum, n. ssp (Odonata, Libellulidae). Nueva subespecie de libélula del Norte de España. Boletín de Ciencias Naturales del Instituto de Estudios Asturianos 36: 75-85.

Ocharan Larrondo FJ (1987) Los Odonatos de Asturias y España. Aspectos sistemáticos y faunísticos. PhD thesis, Oviedo, Spain: Universidad de Oviedo.

Outomuro Priede D (2011) Posibles causas evolutivas de la variabilidad morfológica en especies ibéricas de Calopteryx Leach, 1815 (Odonata). PhD thesis, Oviedo, Spain: Universidad de Oviedo.

Outomuro D, Torralba-Burrial A, Ocharan FJ (2010) Distribution of the Iberian Calopteryx damselflies and its relation with bioclimatic belts: Evolutionary and biogeographic implications. Journal of Insect Science, 10: 61. doi: 10.1673/031.010.6101

Parr AJ (2010) Monitoring of Odonata in Britain and possible insights into climate change. BioRisk 5: 127-139. doi: 10.3897/biorisk.5.846

Pinniger DB (2010) Saving our heritage. Pest management in museums and historic houses. Outlooks on Pest Management 21: 239-241. doi: 10.1564/21oct12

Reguzzi MC, Gariboldi S, Chiappini E (2011) Preliminary observations on the use of low temperatures in the cultural heritage protection. Journal of Entomological and Acarological Research 43: 191-196. 
Rivas-Martínez S (1987) Memoria del mapa de series de vegetación de España 1:400.000. Instituto Nacional para la Conservación de la Naturaleza, Madrid, 268 pp.

Rivas-Martínez S, Penas A, Díaz TE (2004) Biogeographic map of Europe. Cartographic Service University of León, León.

Termaat T, Kalkman VJ, Bouwman JH (2010) Changes in the range of dragonflies in the Netherlands and the possible role of temperature change. BioRisk 5: 155-173. doi: 10.3897/biorisk.5.847

Torralba Burrial A (2008) Estado ecológico, comunidades de macroinvertebrados y de odonatos de la red fluvial de Aragón. PhD thesis, Oviedo, Spain: Universidad de Oviedo.

Torralba-Burrial A (2009) Odonatofauna ibérica y cambios recientes. In: Sánchez A, Pérez J, Jiménez E, Tovar E (Eds) Los Odonatos de Extremadura. Consejería de Industria, Energía y Medio Ambiente, Junta de Extremadura, Mérida, 309-318.

Torralba-Burrial A, Ocharan FJ (2007a) Protocolo para la evaluación del estado ecológico de la red fluvial de Aragón (NE de España) según sus comunidades de macroinvertebrados bentónicos. Limnetica 26: 149-162.

Torralba-Burrial A, Ocharan FJ (2007b) Comparación del muestreo de macroinvertebrados bentónicos fluviales con muestreador Surber y con red manual en ríos de Aragón (NE Península Ibérica). Limnetica 26: 13-24.

Torralba-Burrial A, Ocharan, FJ (2009) Two gynandromorphs of Sympetrum striolatum (Charpentier, 1840) (Odonata: Libellulidae). Entomological Science 12: 182-187. doi: 10.1111/j.1479-8298.2009.00321.x

Verdú JR, Galante E (Eds) (2009) Atlas de los Invertebrados Amenazados de España (Especies En Peligro Crítico y En Peligro). Dirección General para la Biodiversidad, Ministerio de Medio Ambiente, Madrid, 340 pp.

Verdú JR, Numa C, Galante E (Eds) (2011) Atlas y Libro Rojo de los Invertebrados amenazados de España (Especies Vulnerables). Dirección General de Medio Natural y Política Forestal, Ministerio de Medio Ambiente, Medio Rural y Marino, Madrid, 1318 pp.

\section{2) Publications using data of this dataset}

Álvarez MA, Torralba-Burrial A (2012) Primera cita de Sympetrum meridionale (Selys, 1841) (Odonata: Libellulidae) para Asturias (norte de la Península Ibérica). Boletín de la Sociedad Entomológica Aragonesa 51: 346.

Brotóns Padilla M, Ocharan FJ, Outomuro D, Torralba-Burrial A (2009) Anaciaeschna isoceles (Müller, 1767) en el ámbito iberobalear (Odonata: Aeshnidae). Boletín de la Sociedad Entomológica Aragonesa 44: 365-374.

Eroukhmanoff F, Outomuro D, Ocharan FJ, Svensson EI (2009) Patterns of phenotypic divergence in wing covariance structure of calopterygid damselflies. Evolutionary Biology 102: 263-274. doi: 10.1007/s11692-009-9057-8

Galante E, Verdú JR (2000) Los Artrópodos de la “Directiva Hábitats” en España. Organismo Autónomo de Parques Nacionales, Ministerio de Medio Ambiente, Madrid, 247 pp.

Martínez JA, Ocharan FJ (2006) Los odonatos de la cuenca alta del río Narcea (Asturias, norte de España). Boletín de la Sociedad Entomológica Aragonesa 38: 279-285. 
Nores Quesada C, García-Rovés González P (Eds) (2006) Libro Rojo de la Fauna del Principado de Asturias. Gobierno del Principado de Asturias y Obra social "la Caixa”, Oviedo, 524 pp.

Ocharan FJ (1980) Catálogo de la Colección de Odonatos (Insecta) del Departamento de Zoología de la Universidad de Oviedo. Boletín de Ciencias Naturales del Instituto de Estudios Asturianos 26: 111-119.

Ocharan FJ (1980) Sobre la presencia en Asturias de Calopteryx haemorrhoidalis occasi Capra, 1945 (Odonata; Zygoptera). Boletín de Ciencias Naturales del Instituto de Estudios Asturianos 25: 129-133.

Ocharan FJ (1983) Brachythemis leucosticta (Burm.) (Odonata: Libellulidae) en el Norte de España. Boletín de Ciencias Naturales del Instituto de Estudios Asturianos 32: 3-9.

Ocharan FJ (1983) Calopteryx haemorrhoidalis asturica, nueva subespecie de caballito del diablo del Norte de España (Odonata; Zygoptera). Boletín de Ciencias Naturales del Instituto de Estudios Asturianos 31: 3-10.

Ocharan FJ (1984) Captura de Gomphus vulgatissimus (L.) en el norte de España (Odonata: Gomphidae). Boletín de Ciencias Naturales del Instituto de Estudios Asturianos, 34: 3-6.

Ocharan FJ (1984) Odonatos capturados en el Parque Nacional de Covadonga ( $N$ de España). Boletín de Ciencias Naturales del Instituto de Estudios Asturianos 34: 63-67.

Ocharan FJ (1985) Odonatos de Extremadura y Salamanca de la colección de Odonatos del Dpto. de Zoología de la Universidad de Oviedo. Boletín de Ciencias Naturales del Instituto de Estudios Asturianos 36: 109-125.

Ocharan FJ (1985) Sympetrum vulgatum ibericum, n. ssp (Odonata, Libellulidae). Nueva subespecie de libélula del Norte de España. Boletín de Ciencias Naturales del Instituto de Estudios Asturianos 36: 75-85.

Ocharan FJ (1987) Nuevos datos sobre los Odonatos de Menorca. Boletín de la Real Sociedad Española de Historia Natural (Sección Biológica) 83: 155-161.

Ocharan FJ (1988) Composición de la odonatofauna Ibérica. Revista de Biología de la Universidad de Oviedo 6: 83-93.

Ocharan FJ (1990) Variabilidad en poblaciones ibéricas de Cordulegaster boltoni (Donovan, 1807) (Odonata, Cordulegastridae). Revista de Biología de la Universidad de Oviedo 7: 109-121.

Ocharan FJ (1990) Variabilidad cromática en los Platycnemididae ibéricos (Odonata: Zygoptera). Oxyura 6: 41-47.

Ocharan FJ (1992) Odonata collected in Morocco and southern Andalucia (Spain). Notulae odonatologicae 3: 143-145.

Ocharan FJ, Torralba-Burrial A (2004) La relación entre los odonatos y la altitud: el caso de Asturias (Norte de España) y la Península Ibérica (Odonata). Boletín de la Sociedad Entomológica Aragonesa 35: 103-116.

Ocharan FJ, Torralba-Burrial A, Outomuro D (2006) Confirmación de la presencia de Anaciaeschna isosceles (Müller, 1767) en Asturias y primera cita para Cantabria (N España) (Odonata: Aeshnidae). Boletín de la Sociedad Entomológica Aragonesa 39: 396.

Ocharan FJ, Torralba-Burrial A, Outomuro D (2007) Brachytron pratense (Müller, 1764) en la Península Ibérica (Odonata, Aeshnidae). Boletín de la Sociedad Entomológica Aragonesa 41: 307-312. 
Ocharan Larrondo FJ (1987) Los Odonatos de Asturias y Espańa. Aspectos sistemáticos y faunísticos. PhD thesis, Oviedo, Spain: Universidad de Oviedo.

Ocharan Larrondo FJ, Anadón Alvarez MA, Melero Cimas VX, Monteserín Real S, Ocharan Ibarra R, Rosa García R, Vázquez Felechosa MT (2003) Invertebrados de la Reserva Natural Integral de Muniellos, Asturias. Consejería de Medio Ambiente del Principado de Asturias and KRK Ediciones, Oviedo, $352 \mathrm{pp}$.

Ocharan R, Ocharan FJ (2002) Odonatos del Valle de Cuartango (Álava). Boletín de la Asociación española de Entomología 26: 97-110.

Ocharan R, Ocharan FJ, Torralba-Burrial A (2012) Primeras citas de Anax parthenope (Sélys, 1839) (Odonata: Aeshnidae) en Asturias (N España). Boletín de la Asociación española de Entomología 36: 465-467.

Outomuro D (2009) Patrones morfológicos latitudinales en poblaciones ibéricas de Calopteryx Leach, 1815 (Odonata, Calopterygidae): posibles causas ambientales y evolutivas. Boletín de la Asociación española de Entomología 33: 299-319.

Outomuro D, Ocharan FJ (2006) Despigmentación alar en Calopteryx xanthostoma (Charpentier, 1825) (Odonata: Calopterygidae). Boletín de la Sociedad Entomológica Aragonesa 39: 360.

Outomuro D, Ocharan FJ (2006) Mordeduras y daños en las alas como resultado del combate territorial en Calopteryx (Odonata: Calopterygidae). Boletín de la Sociedad Entomológica Aragonesa 39: 421-422.

Outomuro D, Ocharan FJ (2010) Gomphus simillimus Sélys, 1840 (Odonata, Gomphidae) en la cuenca del Segura y el sur de la cuenca del Duero (SE y Centro de España). Boletín de la Asociación española de Entomología 34: 245-248.

Outomuro D, Ocharan, FJ (2011) The larval-life history of Calopteryx virgo meridionalis in Northern Spain and the voltinism in the South-western European species of the genus Calopteryx (Odonata: Calopterygidae). Entomologia Generalis 33: 125-135. doi: 10.1127/ entom.gen/33/2011/125

Outomuro D, Ocharan FJ, Herrero F, Pérez-Andueza G (2010) Primera cita de Oxygastra curtisii (Dale, 1834) para la provincia de Ávila (Odonata: Corduliidae). Boletín de la Sociedad Entomológica Aragonesa 46: 615-616.

Outomuro D, Torralba-Burrial A, Ocharan FJ (2010) Distribution of the Iberian Calopteryx damselflies and its relation with bioclimatic belts: Evolutionary and biogeographic implications. Journal of Insect Science, 10: 61.

Outomuro Priede D (2011) Posibles causas evolutivas de la variabilidad morfológica en especies ibéricas de Calopteryx Leach, 1815 (Odonata). PhD thesis, Oviedo, Spain: Universidad de Oviedo.

Rodríguez-Martínez S, Torralba-Burrial A (2012) Teratología en el paraprocto derecho de una exuvia de Aeshna cyanea (Müller, 1764) (Odonata: Aeshnidae). Boletín de la Sociedad Entomológica Aragonesa 51: 321-322.

Rodríguez-Martínez S, Outomuro D, Ocharan FJ (2011) Odonatos de la cuenca baja del Porcía y alrededores (Asturias, norte de España). Boletín de la Sociedad Entomológica Aragonesa 48: 484-486.

Saloña Bordas MI, Ocharan FJ (1984) Odonatos de Vizcaya. I. Zigópteros. Cuadernos de Investigación Biológica (Bilbao), 5: 45-56. 
Saloña Bordas MI, Ocharan FJ (1984) Odonatos de Vizcaya. II. Anisópteros. Cuadernos de Investigación Biológica (Bilbao), 6: 1-10.

Torralba Burrial A (2008) Estado ecológico, comunidades de macroinvertebrados y de odonatos de la red fluvial de Aragón. PhD thesis, Oviedo, Spain: Universidad de Oviedo.

Torralba-Burrial A (2009) Estado ecológico, comunidades de macroinvertebrados bentónicos y de odonatos de la red fluvial de Aragón. Consejo Económico y Social de Aragón, Zaragoza, $224 \mathrm{pp}$.

Torralba-Burrial A (2009) Odonatofauna ibérica y cambios recientes. In: Sánchez A, Pérez J, Jiménez E, Tovar E (Eds) Los Odonatos de Extremadura. Consejería de Industria, Energía y Medio Ambiente, Junta de Extremadura, Mérida, 309-318.

Torralba-Burrial A (2011) Les llibélules d'Asturies. Ciencies, Cartafueyos Asturianos de Ciencia y Teunoloxía 1: 54-79.

Torralba-Burrial A, Alonso-Naveiro M (2009) Las comunidades de libélulas (Odonata) del Parque Natural de Sierra de Cebollera (La Rioja, N España). Zubia 27: 7-52.

Torralba-Burrial A, Alonso-Naveiro M (2010) Biodiversidad de odonatos de la sierra de Fonfría y cuenca del Jiloca (Teruel): faunística. Xiloca 38: 111-147.

Torralba-Burrial A, Alonso-Naveiro M (2011) Biodiversidad de odonatos de la sierra de Fonfría y cuenca del Jiloca (Teruel): análisis de comunidades. Xiloca 39: 151-168.

Torralba-Burrial A, Mezquita I (2009) Fallos en reconocimiento de pareja en libélulas: cinco tándems intrasexuales inter e intraespecíficos (Odonata: Lestidae, Coenagrionidae y Gomphidae). Boletín de la Sociedad Entomológica Aragonesa 44: 522-524.

Torralba-Burrial A, Ocharan FJ (2001) La calidad de las aguas del río Ara y sus comunidades de macroinvertebrados bentónicos. Sobrarbe. Revista del Centro de Estudios de Sobrarbe 7: 9-73.

Torralba-Burrial A, Ocharan FJ (2002) Valoración preliminar del estado ecológico de los ríos del Parque Nacional de Ordesa y Monte Perdido (Huesca) según sus comunidades de macroinvertebrados bentónicos. Sobrarbe. Revista del Centro de Estudios de Sobrarbe 8: 127-164.

Torralba-Burrial A, Ocharan FJ (2003) Emergencia tardía y voltinismo en Sympetrum fonscolombei (Odonata: Libellulidae). Boletín de la Sociedad Entomológica Aragonesa 33: 279-280.

Torralba-Burrial A, Ocharan FJ (2004) Deformación abdominal en Lestes viridis (Van der Linden, 1825) (Odonata: Lestidae). Boletín de la Sociedad Entomológica Aragonesa 34: 273.

Torralba-Burrial A, Ocharan FJ (2004) Fallo en la emergencia en Aeshna juncea (Odonata: Aeshnidae). Boletín de la Sociedad Entomológica Aragonesa 35: 279.

Torralba-Burrial A, Ocharan FJ (2004) Frogs as preys of dragonflies. Notulae Odonatologicae, 6: $42-44$.

Torralba-Burrial A, Ocharan FJ (2004) Pareja heterospecífica en el género Lestes Leach, 1815 (Odonata: Lestidae). Boletín de la Sociedad Entomológica Aragonesa 35: 297-298.

Torralba-Burrial A, Ocharan FJ (2004) Presencia y comportamiento invernal de adultos de Sympetrum striolatum en el NE de España (Odonata: Libellulidae). Boletín de la Asociación española de Entomología 28: 189-191.

Torralba-Burrial A, Ocharan FJ (2004) Tándem heterospecífico en el género Onychogomphus Sélys, 1854 (Odonata: Gomphidae). Boletín de la Asociación española de Entomología 28: 181-183. 
Torralba-Burrial A, Ocharan FJ (2005) Catálogo de los odonatos de Aragón (Odonata). Catalogus de la entomofauna aragonesa 32: 3-25.

Torralba-Burrial A, Ocharan FJ (2005) Deformidad abdominal en Coenagrion mercuriale (Charpentier, 1825). Boletín de la Sociedad Entomológica Aragonesa 36: 369-370.

Torralba-Burrial A, Ocharan FJ (2005) Larga distancia recorrida en una emergencia fallida en Aeshna cyanea (Odonata: Aeshnidae). Boletín de la Sociedad Entomológica Aragonesa 36: 220.

Torralba-Burrial A, Ocharan FJ (2005) Primera cita de Ischnura elegans (Van der Linden, 1820) y Ceriagrion tenellum (Villers, 1789) (Odonata: Coenagrionidae) para Teruel (NE de España). Boletín de la Sociedad Entomológica Aragonesa 36: 284.

Torralba-Burrial A, Ocharan FJ (2005) Primera cita de Sympetrum vulgatum ibericum Ocharan, 1985 (Odonata, Libellulidae) para la provincia de Zaragoza. Boletín de la Sociedad Entomológica Aragonesa 36: 350.

Torralba-Burrial A, Ocharan FJ (2006) Confirmación de la presencia de Coenagrion mercuriale (Charpentier, 1825) e Ischnura elegans (Van der Linden, 1820) en la provincia de Zaragoza (NE España). Boletín de la Sociedad Entomológica Aragonesa 39: 284

Torralba-Burrial A, Ocharan FJ (2006) Deformación abdominal en Coenagrion puella (Linnaeus, 1758) (Odonata: Coenagrionidae). Boletín de la Sociedad Entomológica Aragonesa 39: 439-440.

Torralba-Burrial A, Ocharan FJ (2006) Deformidad abdominal en Pyrrhosoma nymphula (Sulzer, 1776) (Odonata: Coenagrionidae). Boletín de la Sociedad Entomológica Aragonesa 39: 437-438.

Torralba-Burrial A, Ocharan FJ (2007) Presencia de Hemianax ephippiger (Burmeister, 1839) (Odonata: Aeshnidae) en la provincia de Huesca (NE España). Boletín de la Sociedad Entomológica Aragonesa 40: 426.

Torralba-Burrial A, Ocharan FJ (2007) Comparación del muestreo de macroinvertebrados bentónicos fluviales con muestreador Surber y con red manual en ríos de Aragón (NE Península Ibérica). Limnetica 26: 13-24.

Torralba-Burrial A, Ocharan FJ (2007) Composición biogeográfica de la fauna de libélulas (Odonata) de la Península Ibérica, con especial referencia a la aragonesa. Boletín de la Sociedad Entomológica Aragonesa 41: 179-188.

Torralba-Burrial A, Ocharan FJ (2007) Dragonflies caught by plants (Odonata: Libellulidae). Entomologia Generalis 30: 301-305.

Torralba-Burrial A, Ocharan FJ (2007) Protocolo para la evaluación del estado ecológico de la red fluvial de Aragón (NE de España) según sus comunidades de macroinvertebrados bentónicos. Limnetica 26: 149-162.

Torralba-Burrial A, Ocharan FJ (2008) Odonata de la red fluvial de la provincia de Teruel (España). Boletín de la Sociedad Entomológica Aragonesa 42: 325-335.

Torralba-Burrial A, Ocharan FJ (2008) Odonata de la red fluvial de la provincia de Huesca (NE España). Boletín de la Sociedad Entomológica Aragonesa 43: 101-115.

Torralba-Burrial A, Ocharan FJ (2008) Odonata del Somontano de Barbastro (Huesca, España). Boletín de la Sociedad Entomológica Aragonesa 42: 267-270.

Torralba-Burrial A, Ocharan FJ (2009) Efectos de diversas piscifactorías aragonesas de trucha arco iris Oncorhynchus mykiss (Walbaum, 1792) sobre las comunidades de macroin- 
vertebrados bentónicos. In: XII Congreso Nacional de Acuicultura, Madrid, 24-26 de noviembre, 732-733.

Torralba-Burrial A, Ocharan FJ (2009) Temporalidad y perturbaciones antrópicas en las comunidades de macroinvertebrados bentónicos de la subcuenca del río Arba (Zaragoza, NE España). Boletín de la Real Sociedad Española de Historia Natural (Sección Biológica) 103: 131-144.

Torralba-Burrial A, Ocharan FJ (2010) Primera cita de Anax parthenope (Sélys, 1839) (Odonata: Aeshnidae) de La Rioja (España). Boletín de la Sociedad Entomológica Aragonesa 46: 418.

Torralba-Burrial A, Ocharan, FJ (2009) Two gynandromorphs of Sympetrum striolatum (Charpentier, 1840) (Odonata: Libellulidae). Entomological Science 12: 182-187. doi: 10.1111/j.1479-8298.2009.00321.x

Torralba-Burrial A, Ocharan FJ (2010) Presencia de Ischnura elegans (Vander Linden, 1829) (Odonata: Coenagrionidae) en 1980 en Louro (Galicia, noroeste de España). Boletín de la Sociedad Entomológica Aragonesa 46: 466.

Torralba-Burrial A, Dugnol Menéndez J, Ocharan FJ (2006) Efectos de tres piscifactorías de salmónidos sobre las comunidades de macroinvertebrados bentónicos de los ríos donde se ubican. In: de Blas I, Velasco M, Montoya R (Eds) IV Congreso Iberoamericano Virtual de Acuicultura (CIVA 2006) 6-XII-2006/15-I-2007. Laboratorio de Ictopatología, Universidad de Zaragoza, Zaragoza, 529-540 (published 2007).

Torralba-Burrial A, Melero VX, Ocharan FJ (2007) Utilización de exuvias de Orthetrum brunneum (Fonscolombe, 1837) (Odonata: Libellulidae) como lugar de cría por Sibianor aurocinctus (Ohlert, 1865) (Araneae: Salticidae). Boletín de la Sociedad Entomológica Aragonesa 41: 344.

Torralba-Burrial A, Outomuro D, Ocharan FJ (2008) Dos ejemplares teratológicos de Coenagrion puella (Linnaeus, 1758) (Odonata: Coenagrionidae). Boletín de la Sociedad Entomológica Aragonesa 42: 352.

Verdú JR, Galante E (Eds) (2006) Libro Rojo de los Invertebrados de España. Dirección General de Conservación de la Naturaleza, Madrid, 411 pp.

Verdú JR, Galante E (Eds) (2009) Atlas de los Invertebrados Amenazados de España (Especies En Peligro Crítico y En Peligro). Dirección General para la Biodiversidad, Ministerio de Medio Ambiente, Madrid, 340 pp.

Verdú JR, Numa C, Galante E (Eds) (2011) Atlas y Libro Rojo de los Invertebrados amenazados de España (Especies Vulnerables). Dirección General de Medio Natural y Política Forestal, Ministerio de Medio Ambiente, Medio Rural y Marino, Madrid, 1318 pp.

VVAA (2012) Bases ecológicas preliminares para la conservación de las especies de interés comunitario en España: Invertebrados. Ministerio de Agricultura, Alimentación y Medio Ambiente, Madrid. 